\title{
Hobbicélú 3d nyomtató szerkezeti hibáinak javítása
}

\author{
Csehi Bálint \\ hallgató, Miskolci Egyetem, Gép- és Terméktervezési Intézet \\ 3515 Miskolc, Miskolc-Egyetemváros, e-mail: cs.balint98@gmail.com \\ Bihari Zoltán \\ egyetemi docens, Miskolci Egyetem, Gép- és Terméktervezési Intézet \\ 3515 Miskolc, Miskolc-Egyetemváros, e-mail: machbz@uni-miskolc.hu
}

\begin{abstract}
Absztrakt
Ez a cikk az FDM technológiával dolgozó, hobbikategóriás 3D nyomtatókról szól. Ezen belül külön elemezzük azokat a hiányosságokat, szerkezeti hibákat, melyek egyszerüen, egy hobbi felhasználó által is könnyen javithatóak. Célul tüztük ki, hogy egy Creality Ender-5 típusú nyomtatón bemutassuk ezeket a legfontosabb hiányosságokat, és a nyomtatót úgy módositsuk, hogy változatlan minöség mellett lényegesen nagyobb nyomtatási sebességre legyen képes.
\end{abstract}

Kulcsszavak: 3D nyomtató, FDM, tervezés

\section{Abstract}

This article is about the hobby-grade 3D printers, that uses FDM printing method. Within this, we analyze the deficiencies and structural defects, which can be easily corrected by a hobby user. We demonstrate these important defects through the upgrading of a Creality Ender-5 type 3D printer. Our goal was to achieve much higher printing speed, with the same or better printing quality than the original printer.

Keywords: 3D printer, FDM, designing

\section{Bevezetés}

Az első Magyarországon széles körben elterjedt 3D nyomtató az Anet A8 egyik változata volt, a Geeetech cég Prusa I3 Pro névre hallgató modell. Bár a nyomtatási képességei igencsak korlátozottak voltak, mégis hasznos tapasztalatnak bizonyult a felhasználói számára. Természetesen eljárt felette az idő, így elöször egy Geeetech A10M-re, majd a Creality Ender-5 nyomtatók kiszorították a piacról. A 3Dee Technologies Kft. 3D nyomtatással, 3D nyomtatók forgalmazásával foglalkozó cégnek köszönhetöen sok tapasztalatra sikerült szert tenni ezen technológia elsajátításában, így felmerült az a lehetőség, hogy vizsgáljuk meg, hogy mi lehet a legtöbb, amit a hobbi célra szánt nyomtatóból ki lehet hozni.

A hobbinyomtatók és ipari nyomtatók között az a legszembetűnőibb különbség, hogy az előbbiek gyártói sok apró részletet illetően hajlamosak nagyvonalúságra, nyilván a költségek csökkentése miatt. Ez azonban sok, olcsón javítható, egyszerü, ám komoly korlátozást jelentő hibalehetőséget is magába foglal. Ezzel együtt, a hobbicélú 3D-nyomtatás jelentős részét képviseli a területnek, és a hobbisták sokszor tudtukon kívül foglalkoznak olyan problémákkal, melyek megoldását a tudományos életben is érdemes lenne publikálni. Ez a munka most ennek a célkitüzésnek igyekszik megfelelni. 


\section{A hobbinyomtatók általános jellemzői}

Az FDM technológiát már 1989-től szabadalom védte, melyet a Stratasys cégcsoport birtokolt [1]. Ez a szabadalom 2010-ig biztosította számukra az egyeduralmat a piacon, ezután azonban megnyílt az út más gyártók előtt is. Ezt követően jelentek meg az olcsó, egyszerü szerkezetü hobbinyomtatók, és vált széles körben elterjedté.

Bár az elmúlt 10 évben nagy fejlődésen mentek keresztül a hobbinyomtatók, a célközönség miatt sok szempontból a mai napig egyszerüek ezek a gépek. A több millió forintos félipari és ipari nyomtatókkal szemben ugyanis ezek árának töredékéért, általában 50-150 ezer forintért szerezhetjük be saját nyomtatónkat, ez azonban sok kompromisszummal jár.

A hobbinyomtatókat általában egyszerü, széles körben elterjedt alkatrészekböl építik, melyekre jellemző a nagy fokú kompatibilitás. Az első nyomtatók váza menetes szárakból, $8 \mathrm{~mm}$ átmérỏjü lineáris köracél tengelyekből és fa, akril vagy alumínium lemezből vágott alkatrészekből álltak. Az alumínium profilt 2016 után kezdték el jellemzően használni, és napjainkra az új típusú hobbikategóriás gépek szinte kizárólag erre épülnek. Jellemzően nem az Európában elterjedt Boschvagy Item-kompatibilis profilokat használják, hanem egy saját változatot, melyet Openbuild V-Slot néven találhatunk meg az interneten.

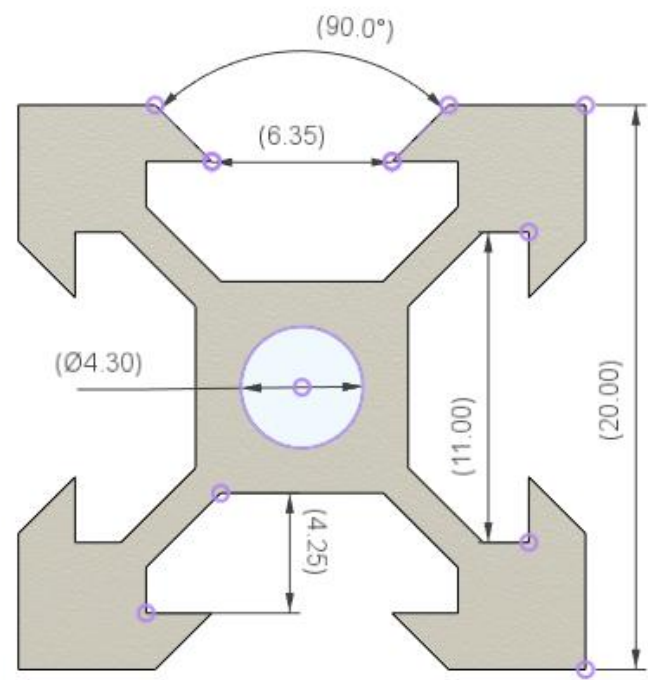

1.ábra. Openbuild V-slot profil keresztmetszete

A gépek többi alkatrészére is az általános kompatibilitás a jellemző, így például különböző típusú extruderekben, nyomtatófejekben is gyakran találunk azonos alkatrészeket, melyek akár teljes mértékben is megegyeznek.

Az alacsony ár másik vonzata az, hogy a nyomtatóhoz nem tartozik semmilyen after-sales támogatás, illetve a garancia érvényesítése is sokszor körülményes. A nyomtatókon futó firmware jellemzően a leginkább elterjedt, nyílt forráskódú Marlin valamelyik változata. Általában a nyomtató megjelenési évére jellemző változatból készítik el a gyári verziót, és ezt később nem frissítik. Remek példa erre, hogy a 2018-ban bemutatott Ender-3 nyomtatók ma legyártott példányain is a Marlin 1.1.5 verziója fut, miközben a marlinfirmware.org weboldalra ellátogatva már a 2.0.7 verziót tölthetjük le. 


\section{A Creality Ender-5 nyomtató}

A Shenzhen Creality 3D Technology Co., Ltd. neve nem ismeretlen a hobbi követöi körében. 2014-es alapításuk óta több mint húszféle 3D nyomtatót terveztek, többnyire az FDM technológiához, de a kínálatukban szerepel néhány SLA/DLP nyomtató is.

Az Ender-5 nyomtatójuk az első nyomtatójuk, amely téglatest alakú vázzal rendelkezik, és a tárgyasztalát nem $\mathrm{Y}$, hanem kizárólag $\mathrm{Z}$ irányban, azaz a függőleges tengelyen mozgatja. A $24 \mathrm{~V}$-os elektronika, illetve a bovdenes rendszerü extruder kialakítás szintén előnye ennek a típusnak, amihez kedvezö, \$250 körüli fogyasztói ár társul. Ezek alapján az egyik legnépszerübb 3D nyomtatós weboldal, az all3dp.com 2019/2020 telének legjobb 3D nyomtatójának választotta a típust, a \$300 és $\$ 500$ alatti kategóriában is [2].

Ugyanakkor, mint minden hobbinyomtató esetében, itt is találni hiányosságokat, hibákat. Egy hobbinyomtató esetén komoly hibának gondolom, hogy a gyári alaplap gyenge, az AtMega 1284P processzor erőforrásai szinte teljesen ki vannak használva, így nem marad szabad kapacitás a filament szenzorra, vagy a különféle, a nyomtatás minőségét javító beállításokra.

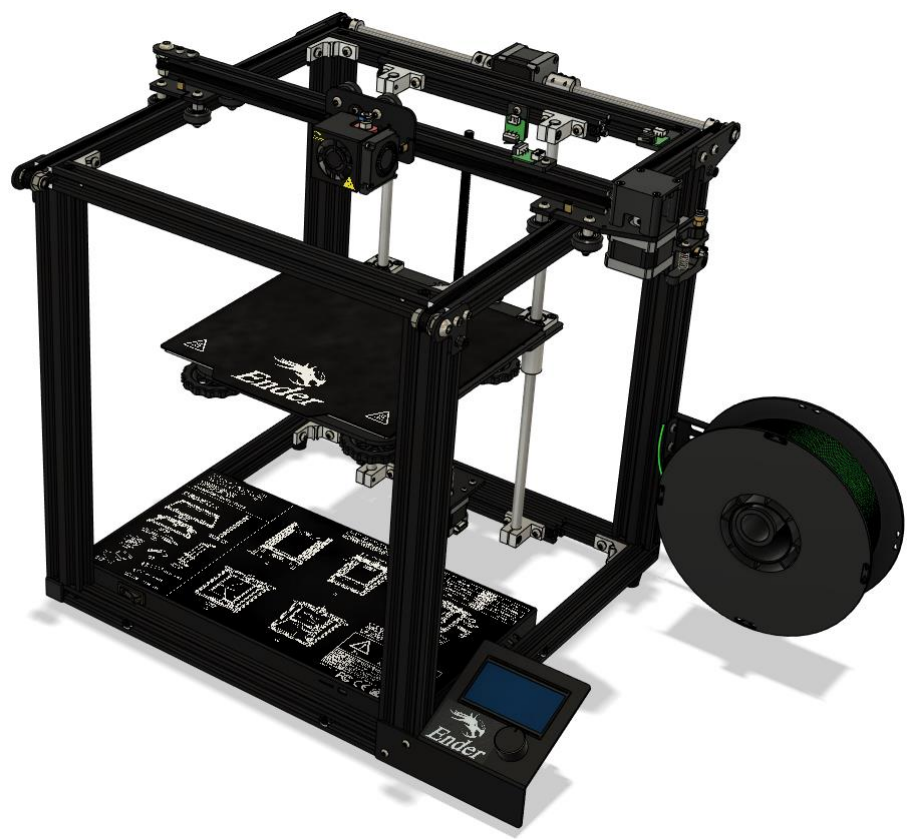

2.ábra. Creality Ender-5 nyomtató 3D modellje.

A vázszerkezetnek is több hibája van, például a tengelyek mozgatását végző bordásszíjak feszessége nem, vagy csak nagyon nehezen állítható, a féloldalas Z-tengely pedig nem teszi lehetővé a nagyobb nyomtatási sebességet. Egész egyszerüen arról van szó, hogy a $230 \mathrm{~mm}$ élhosszúságú, négyzet alakú tárgyasztal, illetve az alatta található tartókonzol nem nyújt megfelelő szilárdságot, így a nyomtatófej $\mathrm{X}$, illetve $\mathrm{Y}$ irányú mozgásával keletkező rezonancia hatására a tárgyasztal $\mathrm{Z}$ tengelytől távol eső vége hajlamos a rezonanciára, ez pedig rontja a nyomtatás felületi minőségét. Problémát jelent az is, hogy rendkívül kis erő hatására is függőleges elmozdulásra képes a tárgyasztal széle, így 
egy nagyobb test nyomtatása során a tárgyasztalra kerülő filament súlya is hatással van a minőségre. További problémákat okoz az, hogy a függöleges tengelyt mozgató trapézmenetes orsó nincs csapágyakkal támasztva, így oldalirányba elmozdulhat, mely szintén pontatlansághoz vezet; valamint az extruder anyaga és kialakítása sem megfelelö.

\section{A Z tengely megerősítése, fejlesztése}

A helyzet végleges megoldásáig egy ideiglenes merevítés került a tárgyasztalt tartó konzol aljára, melyet a nyomtatón készítettem el, PETG alapanyagból. Jelen esetben azért ezt az anyagot választottam az elterjedtebb PLA-val szemben, mert magasabb hőmérsékletet bír ki, így a tárgyasztal alja felől érkező, hosszan tartó hőterhelés hatására sem fog meglágyulni.

Ez a merevítés már önmagában sokkal stabilabbá tette a tárgyasztalt, így úgy gondolom, jól mutatja, hogy milyen apró, de fontos dolgokról hajlamosak sokszor elfeledkezni a gyártók a hobbinyomtatók esetében.

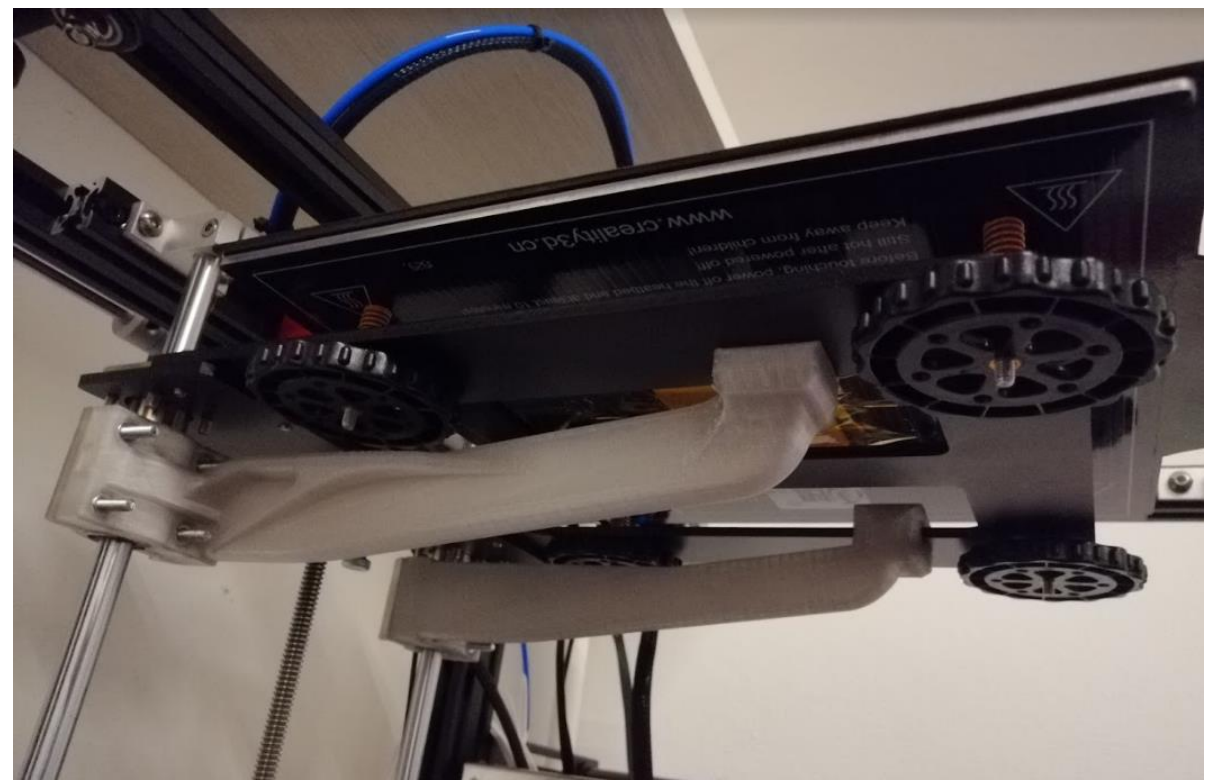

3.ábra. A tárgyasztal aljára szerelt merevités

Természetesen ez csak átmeneti megoldásként merült fel, a problémára a végleges megoldást a másik oldali Z-tengely beszerelése fogja jelenteni. Ehhez egy, a gyárival azonos menetprofilú trapézmenetes orsót, azonos tengelycsatlakozót és léptetőmotort, illetve $8 \mathrm{~mm}$ átméröjü köracél tengelyeket fogok használni, azonban a gyári, LMKL típusú, hosszabb kialakítású csapágyak helyett LMF típusú, itthon könnyebben beszerezhető csapágyak fognak helyet kapni a gépen. Fontos lépés lesz, hogy a több darabból álló, tárgyasztalt tartó konzolt egyetlen, $6 \mathrm{~mm}$ vastag szénszálas lemezből fogom elkészíttetni, mellyel egyrészt a $Z$ irányba mozgó tömeget tudom csökkenteni, másrészt a tárgyasztalt tartó konzol válik merevebbé.

A második $\mathrm{Z}$ tengely beszerelését az teszi lehetővé, hogy a gyári elektronikát tartó dobozt kiszereltem, és a tápegységet elforgatva, más helyre szereltem vissza, így szabaddá vált az alumínium 
profilok belső oldala, ahova a lineáris elemeket és a motort rögzíteni tudom. Egyúttal a gyári alaplapot is ki szándékozom cserélni, és az új típus már lehetővé teszi a több motor és végállás-kapcsoló használatát a $\mathrm{Z}$ tengelyen.

\section{Szíjfeszítők és bordásszíjak}

A gyári poliuretán bordásszíjakkal, illetve a szíjfeszítővel is problémát tapasztaltam. A nyomtatási sebesség növeléséhez a gyorsulásokat is növelni kell, ez viszont a mozgó részek tömege miatt problémát jelent. Az irányváltáskor fellépő erők hatására ugyanis a bordásszíj megnyúlik, ez pedig a nyomtatáson is meglátszik, szellemkép formájában. Ezt a jelenséget ghosting néven ismerik, és a szíjak minőségén túl a nem megfelelő feszítés is kiválthatja.

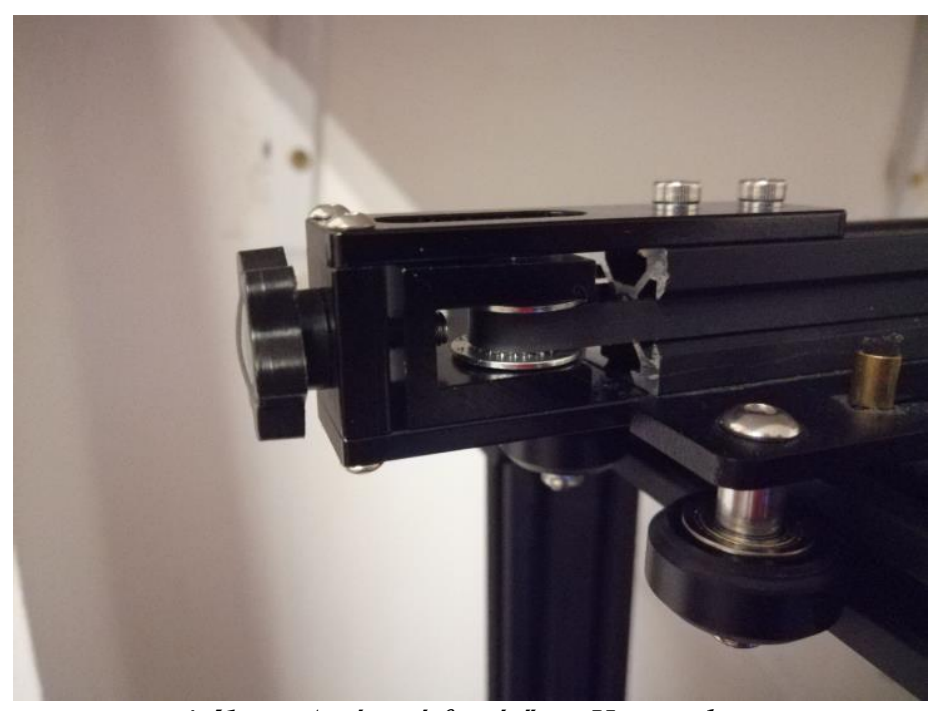

4.ábra: Az új szíjfeszitő az X tengelyen

A gyári vezetőgörgők pozíciója állítható ugyan, azonban ehhez az egész konzolt mozgatni kell, így pedig nehéz pontosan beállítani a megfelelő feszességet. Laza szíjnál ghosting lép fel, túlfeszített szíjak esetén pedig a motornak kell nagyobb erőt kifejtenie, ami melegedéshez vezet, illetve hatással van a finom részletek nyomtatására.

Az X tengely szíjfeszítőjét egyszerübb volt cserélni, azonban az Y tengelyen a szíjfeszítő konzolja egyben sarokmerevítő funkciót is betölt, így egy alumínium profilokhoz való sarokmerevítöt is fel kellett szerelni, a váz stabilitásának megőrzése érdekében.

A szíjfeszítők mellett a bordásszíjakat is cserélni kellett. Az új szíjak négy darab, $0,75 \mathrm{~mm}$ vastag acélszál fonatot tartalmaznak, így a mozgás közbeni irányváltáskor sokkal kisebb a rugalmas alakváltozás a szíjban.

\section{Az extruder átalakítása}

A gyári extruder pár hét használat után a 4. ábrán látható helyen eltört. Az internetes fórumokon végzett kutatásom alapján ez egy általános hibajelenség, amely nem csupán az Ender-5 nyomtatót 
érinti, hanem a Creality összes többi modelljét, melyen ezt a típusú, mủanyag extrudert használták. Úgy gondolom, a hibának köze van a fröccsöntés után préselt menetes betétnek, ami feszültséget okozott az anyagban.

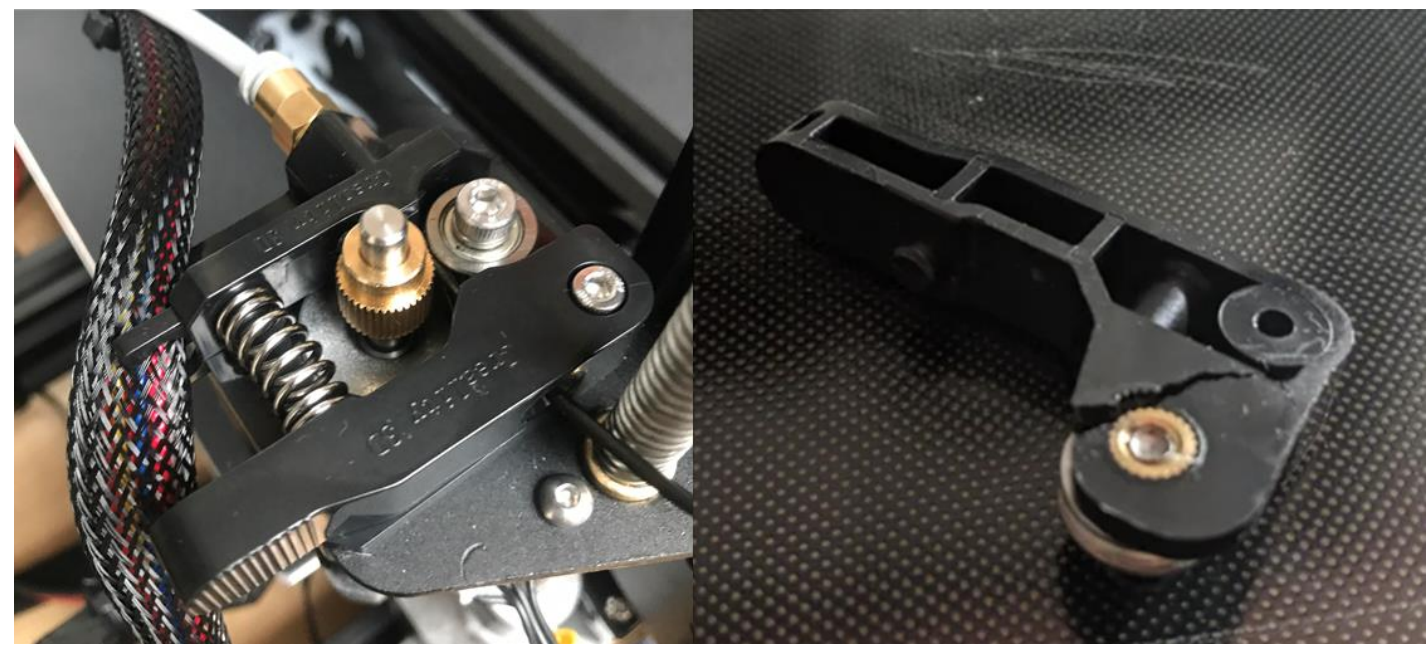

5.ábra: Balra a gyári extruder, jobbra a törött feszitökar

Ezt az extrudert egy BMG típusú, ún. dual-drive megoldásra cseréltem le. A gyári extruder egy egyenes fogazású fogazott görgő és egy hornyos felszínü, csapágyazott támasztógörgő között fog rá a filamentre, ezzel szemben a dual-drive megoldásoknál két hornyos felszínü, finoman recézett görgőt találunk, melyek közvetlen fogaskerék-kapcsolatban állnak egymással. Ezáltal sokkal nagyobb erővel képes tolni a filamentet, illetve sokkal kisebb a megcsúszás veszélye. Ezen kívül az extrudálás pontosságát is javítja, hiszen egy 3:1 áttételü fogaskeréken keresztül hajtja a léptetőmotor, így kisebb fúvókával is pontos marad a nyomtató.

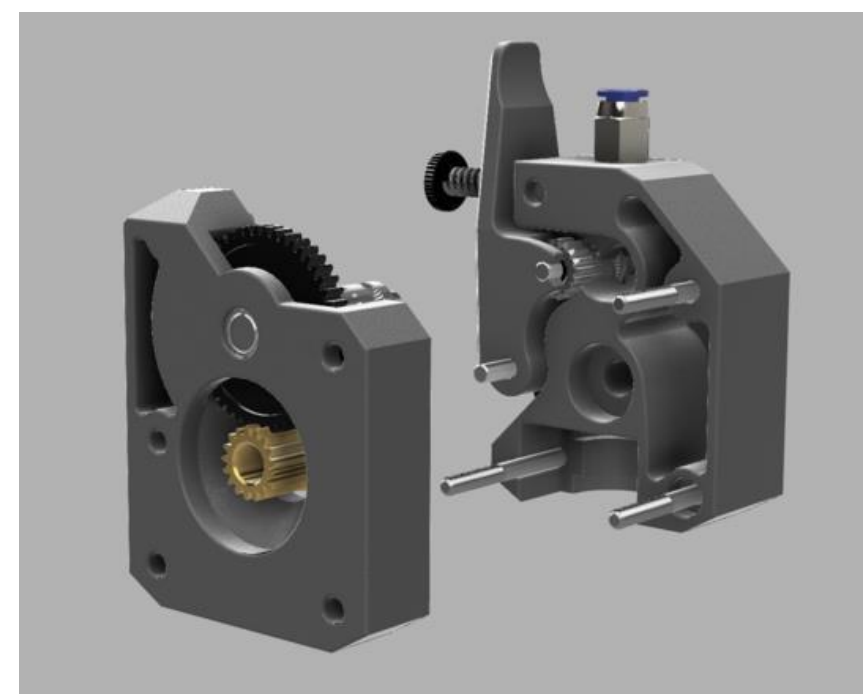

6.ábra: $B M G$ extruder $C A D$-modellje. 


\section{Elektronika és firmware}

Mivel a gyári alaplapon nem volt már bővítési lehetőség, szükségessé vált az alaplap cseréje is. Az új alaplap a Shenzhen Big Tree Technology Co., Ltd. terméke, az SKR 1.4T jelü alaplap. Ez kifejezetten 3D nyomtatók, CNC esztergák és lézergravírozók számára készített alaplap, amely támogatja a legújabb típusú motorvezérlőket, képernyőket, illetve a számtalan egyéb szenzort és kiegészítőt, melyekkel pontosabbá, üzembiztosabbá vagy komfortosabbá tehetjük a saját eszközünket.

Mivel ez az alaplap már cserélhető motorvezérlőkkel rendelkezik, a gyári lapon található A4988 típusú chipek helyett a Trinamic TMC2209 vezérlöje került a gépbe. Ez hatalmas előrelépést jelent, hiszen míg az előbbi elektronika a léptetőmotorok fizikai lépését 16 részre tudja osztani, addig a TMC család vezérlői 256 mikrolépésre képesek. Ennek következménye, hogy nagyobb pontosságra képesek, finomabb gyorsulásokat tudnak elérni, és egyúttal a zajhatás is csökken. Hátrányuk ugyanakkor, hogy kisebb áramokat képesek csak kezelni, illetve jobban melegednek, mint a gyári verziók. Mivel a második $\mathrm{Z}$ tengely miatt a gyári elektronika doboza eleve kikerült a gépből, illetve mivel az alaplap mérete nem egyezik a gyáriéval, egy 3D nyomtatott, jól szellőző házba került.

Mivel az új alaplapon már egy 32 bites ARM-Cortex típusú processzor található, az alaplap támogatja a Marlin 2.0-tól újabb verzióit is. Jelenleg a 2.0.4.4 verzió fut az alaplapon, ami az átalakítás időpontjában elérhető legutolsó, bugfix verzió volt.

Az új alaplappal egyúttal megnyílt a lehetőség egy sor további funkció használatára is, mint a wifikapcsolaton keresztüli vezérlés, a nyomtatófej parkoló pozícióba küldése a nyomtatás szüneteltetése esetén, az automata filament csere, illetve a filament mozgását figyelö filament szenzor, mely nem csak a kifogyó alapanyagra figyelmeztet, de az eltört, elszakadt, vagy bármilyen ok miatt elakadó, megszoruló filamentet is érzékeli $[5,6]$

Az elektronikai átalakítások közé tartozik még a nyomtatófej két apróbb változtatása: a gyári, $40 \mathrm{~W}$ teljesítményű fütőelem helyett egy jobb minőségü, $50 \mathrm{~W}$ fütőelemet kapott a nyomtatófej, az NTC típusú termisztort pedig egy K-típusú hőelemre cseréltem. Az erősebb processzor nyújtotta, pontosabb PID-szabályozókörrel és ezekkel az alkatrészekkel lehetővé vált a gyáritól nagyobb nyomtatási sebesség elérése is, miközben a pontosabb fejhőmérséklet egyenletesebb extrudálást tesz lehetővé, így javítva a nyomtatási minőséget.

\section{8. Összefoglalás}

A hobbiszintü 3D nyomtatókról szerzett tapasztalataimat összegezve, célszerübb egy kicsivel többet áldozni az első nyomtatónkra. Alapkövetelmény legyen az alumínium profilból készült, erős váz, a füthető tárgyasztal, és a Előny, ha a nyomtató 32 bites alaplappal van szerelve, fém extruder van rajta, illetve ha alumínium profilból készült a váza. Ez utóbbi abból a szempontból fontos, hogy egyszerübb a további fejlesztése, illetve komolyabb átalakítás nélkül is lehetőségünk van lineáris sínek felszerelésére, amennyiben erre szükségünk lenne.

A számunkra ideális nyomtató kiválasztásakor vegyük figyelembe, hogy milyen anyagokkal kívánunk majd dolgozni, ugyanis a leginkább elterjedt, nyitott munkaterü, bovdenes extruderü nyomtatók nem alkalmasak a TPU, ABS, ASA, polikarbonát és poliamid anyagok nyomtatására. Ha csak TPU-ra lesz szükségünk, egy direkt extruderrel szerelt nyomtató már elegendő a számunkra, azonban, ha a többi felsorolt anyagot szeretnénk nyomtatni, minimum egy zárt munkaterü nyomtatóra lesz szükségünk. Ebben az esetben elöny lehet, bár nem szükségszerü, ha a nyomtatótér külön légkeverő ventilátorokkal és fütőtesttel van ellátva. Fontos szempont legyen a munkatér mérete is, 
hiszen ezen később csak jelentős átépítéssel tudunk változtatni, így pedig egyszerübb rögtön a számunkra megfelelő méretủ géppel kezdeni.

\section{Köszönetnyilvánítás}

A cikkben ismertetett kutatómunka az Innovációs és Technológiai Minisztérium ÚNKP-20-1-1. kódszámú Új Nemzeti Kiválóság Programjának a Nemzeti Kutatási, Fejlesztési és Innovációs Alapból finanszírozott szakmai támogatásával készült.

\section{Irodalom}

[1] US5121329A szabadalom, https://patents.google.com/patent/US5121329A/en Letöltve: 2020.12.05.

[2] https://all3dp.com/1/creality-ender-5-review-3d-printer-specs/ Letöltve: 2020.12.05.

[3] Fülöp, Gy. Horváth, M., Kodácsy, J.: Gyors prototípusgyártás marással, Fiatal Műszakiak Tudományos Ülésszaka. Kolozsvár, 2003. március 21-22.

[4] Torta, S., Torta, J.: 3D Printing - An Introduction, Mercury Learning and Information kiadó, Boston, USA, 2019

[5] github.com/bigtreetech Letöltve: 2020.12.05.

[6] marlinfw.org, github.com/MarlinFirmware Letöltve: 2020.12.05. 